\title{
This abstract has also been published as $\mathrm{O} 23$
}

From Frontiers of Retrovirology 2011

Amsterdam, The Netherlands. 3-5 October 2011

Published: 3 October 2011

doi:10.1186/1742-4690-8-S2-P44

Cite this article as: : This abstract has also been published as $\mathrm{O} 23$.

Retrovirology 2011 8(Suppl 2):P44.

Submit your next manuscript to BioMed Central and take full advantage of:

- Convenient online submission

- Thorough peer review

- No space constraints or color figure charges

- Immediate publication on acceptance

- Inclusion in PubMed, CAS, Scopus and Google Scholar

- Research which is freely available for redistribution 